\title{
Studi Etnofarmasi pada Suku Anak Dalam (SAD) di Desa Semambu Kecamatan Sumay Kabupaten Tebo Provinsi Jambi
}

\author{
Ethnopharmaceutical Study of Suku Anak Dalam (SAD) People in \\ Semambu Village, Jambi
}

\author{
Indah Asridawati*, Santi Perawati, Yulianis \\ Program Studi Farmasi, STIKes Harapan Ibu, Jambi \\ Jl. Tarmizi Kadir No.71, Pakuan Baru, Kecamatan Jambi Selatan, Kota Jambi, Jambi \\ *Corresponding author email: indahastridawati@gmail.com
}

Received 09-03-2020 Accepted 23-06-2020 Available online 01-07-2020

\begin{abstract}
ABSTRAK
Suku Anak Dalam (SAD) merupakan suku minoritas yang mendiami kawasan hutan di Provinsi Jambi. SAD memiliki tradisi pengobatan untuk berbagai penyakit yang diwariskan dari leluhur dengan memanfaatkan sumber bahan alam yang ada. Studi ini bertujuan untuk mengetahui sumber bahan alam yang ada di daerah SAD dan kegunaan bahan alam tersebut untuk tujuan pengobatan berbagai jenis penyakit. Jenis penelitian ini adalah penelitian deskriptif menggunakan metode kualitatif dan teknik pengambilan sampel snowball sampling terhadap dua orang informan yaitu Tumenggung Bujang Kabut dan Menti selaku dukun yang mengetahui pengobatan SAD melalui wawancara open-ended interview mengenai sumber bahan alam yang ada di Desa Semambu. Hasil penelitian menunjukkan bahwa penyakit yang sering dialami SAD adalah demam, gatalgatal, cacingan, buang air besar (BAB) berdarah, batuk, flu, sakit gigi, sesak nafas, sakit perut, dan perawatan pasca melahirkan. Bagian bahan alam yang digunakan meliputi daun, buah, batang, akar, kulit, biji, empedu, daging, taring, dan lemak. Metode pengolahan yang digunakan antara lain direbus, ditumbuk, dibakar, dan diperas. Sedangkan penggunaan dilakukan dengan cara diminum, dimakan, dioles, ditempel, dan digosok. Sumber bahan alam yang digunakan di Desa Semambu, Kecamatan Sumay, Kabupaten Tebo, Provinsi Jambi untuk pengobatan terdiri dari 27 spesies, yaitu 22 spesies tumbuhan dan lima spesies hewan. Penyakit yang paling sering diobati dengan bahan alam yaitu penyakit kulit (gatal-gatal). Bagian tanaman yang paling banyak digunakan adalah daun dan cara pengolahan yang paling sering dilakukan yaitu dengan cara ditumbuk dan direbus.
\end{abstract}

Kata kunci: : Desa Semambu, etnofarmasi, Suku Anak Dalam (SAD). 


\begin{abstract}
Suku Anak Dalam (SAD) is a minority tribe inhabiting forest areas in Jambi Province. SAD people traditionally treat various diseases using natural resources. This ethnopharmaceutical study aims to find out the source of natural products used by SAD people and the local knowledge of the utilization of those for medicinal purposes. It was a descriptive study using qualitative methods and snowball sampling techniques. Two shamans, Tumenggung Bujang Kab and Menti, were involved as the informants of this study. The results of the study suggested that fever, itching, intestinal worms, hemorrhoid, cough, flu, toothache, shortness of breath, stomachache, and post-partum treatment were the diseases that were commonly experienced by SAD people. The part of natural products frequently used include leaves, fruit, stems, roots, bark, seeds, bile, meat, fangs, and fat. Those materials were processed by boiling, mashing, burning, and squeezing methods, which were commonly applied by drinking, eating, smearing, sticking, and rubbing. There were 27 species, consisting of 22 plants and five animals, used as a source of natural ingredients for medicinal purposes in Semambu Village, Sumay District, Tebo Regency, Jambi Province. The most commonly treated disease was itching. The most frequently used plant parts and processing method were leaves as well as mashing and boiling, respectively.
\end{abstract}

Key words: ethnopharmacy, Semambu Village, Suku Anak Dalam (SAD).

\section{Pendahuluan}

Suku Anak Dalam

merupakan salah satu suku minoritas yang ada di Pulau Sumatera tepatnya di daerah Provinsi Jambi. SAD yang berada di Provinsi Jambi salah satunya terdapat di Kecamatan Sumay, Kabupaten Tebo. Masyarakat SAD yang berada di Kecamatan Sumay ini awalnya berasal dari daerah "Telay" yaitu daerah Rantau Limau Manis, Hitam Ulu, Tabir sekitarnya (Kabupaten Merangin). Mereka sampai ke Sumay dikarenakan wilayah mereka di Telay sudah habis dijadikan kebun perusahaan dan transmigrasi sehingga SAD terpaksa harus meninggalkan daerah tersebut dan saat itu kebetulan wilayah Sumay masih rimba dan secara jarak cukup dekat dengan Telay, maka mereka memutuskan untuk pindah ke daerah Sumay (Willy et al., 2019).

$$
\text { Sistem kepercayaan SAD }
$$

berbeda dengan agama-agama yang ada. Sistem kepercayaan SAD tidak memiliki nama tertentu, SAD mempercayai adanya para dewa dan fungsi dewa hanyalah sebagai perantara kepada Tuhan (Saleh, 2014). Akhir-akhir ini penelitian etnofarmasi mengenai pengetahuan dan pemanfaatan tanaman obat oleh masyarakat lokal juga telah banyak dilakukan salah satunya terhadap SAD. Etnofarmasi merupakan ilmu yang mempelajari penggunaan obat dan cara pengobatan yang dilakukan oleh suatu etnik atau suku bangsa tertentu. Berdasarkan hasil penelitian etnofarmasi yang dilakukan oleh Perawati et al. (2019) diketahui beberapa jenis tanaman 
maupun satwa dan manfaatnya yang digunakan oleh SAD di Desa Muara Kilis, Kecamatan Tengah Ilir, Kabupaten Tebo, Provinsi Jambi. Selain itu, studi etnobotani tumbuhan obat yang digunakan SAD di Kecamatan VII Koto Kabupaten Tebo Provinsi Jambi juga telah dilakukan oleh Indriati (2014) dan diketahui jenis tumbuhan obat yang digunakan oleh SAD untuk menangani berbagai penyakit.

Berdasarkan beberapa penelitian tersebut, diketahui penelitian etnofarmasi telah dilakukan di berbagai Desa dan Kecamatan yang ada di Kabupaten Tebo, sedangkan untuk Desa Semambu, Kecamatan Sumay belum pernah dilakukan studi etnofarmasi. Oleh karena itu, peneliti tertarik untuk melakukan studi etnofarmasi tentang sumber bahan alam yang ada di wilayah Suku Anak Dalam (SAD) di Desa Semambu, Kecamatan Sumay, Kabupaten Tebo sehingga dapat memberikan informasi dan pengetahuan tentang sumber bahan alam yang dimanfaatkan SAD dalam pengobatan.

\section{Metode Penelitian}

Lokasi dan Waktu Penelitian

Penelitian ini dilakukan dari bulan Oktober 2019 hingga Februari 2020 di Desa Semambu, Kecamatan Sumay, Kabupaten Tebo, Provinsi Jambi dan Laboratorium Penelitian STIKes Harapan Ibu Jambi.

\section{Desain Penelitian}

Penelitian ini merupakan penelitian deskriptif yang menggunakan metode kualitatif dan teknik pengambilan sampel yakni snowball sampling melalui wawancara openended interview. Informan yang dipilih dalam penelitian ini adalah tumenggung SAD yang berada di Desa Semambu yaitu Tumenggung Bujang Kabut dan satu orang warga SAD atau "Orang Pintar" yang disebut dukun yang sangat mengetahui tentang pengobatan SAD di Desa Semambu. Data penelitian mengenai informasi sumber bahan alam yang berkhasiat obat diperoleh dari mewawancarai Tumenggung Bujang Kabut sebagai informan kunci dan dilanjutkan dengan mencocokkan informasi yang diperoleh dari informan kunci dengan melakukan wawancara langsung dengan "Orang Pintar" mengenai sumber bahan alam berkhasiat obat meliputi nama daerah, manfaat, bagian yang digunakan, cara pengolahan, cara penggunaan beserta lama penggunaan.

Penelitian diilakukan dengan cara mengumpulkan informasi dari sumber bahan alam yang ada di daerah Semambu serta pemanfaatannya dari informan selanjutnya peneliti melakukan validasi terhadap data yang diperoleh dengan menjelaskan kembali data yang didapat kepada informan untuk menyamakan persepsi berdasarkan interpretasi peneliti atas wawancara dengan maksud yang disampaikan informan, sehingga informasinya betul-betul sesuai dengan persepsi informan. Data tersebut dideskripsikan dengan sistem tabulasi. 


\section{Sumber Data}

Jenis data dalam penelitian ini berupa data kualitatif dengan sumber data yaitu informasi yang diperoleh dari informan mengenai sumber bahan alam berupa tumbuhan dan hewan yang digunakan sebagai kebutuhan primer maupun pengobatan yang meliputi nama daerah, manfaat, bagian yang digunakan, cara pengolahan, cara penggunaan beserta lama penggunaan.

Sumber bahan alam yang diambil datanya adalah sumber bahan alam yang dinilai berguna dalam pengobatan dan sebagai kebutuhan primer. Sumber bahan alam tersebut diambil di kawasan hutan yang dimanfaatkan SAD Desa Semambu sebagai tempat untuk memperoleh kebutuhan sehari-hari dan obat-obatan. Radius kedalamannya sekitar \pm 300 meter dari pinggir hutan. Sumber bahan alam yang selanjutnya dideterminasikan hanyalah sumber bahan alam yang digunakan untuk pengobatan oleh SAD Desa Semambu, Kecamatan Sumay, Kabupaten Tebo Provinsi Jambi.

\section{Pengumpulan Data}

Data diambil berdasarkan informasi dari informan yang mengetahui tentang sumber bahan alam tersebut. Adapun teknik pengumpulan data adalah sebagai berikut:

\section{Wawancara}

Mengumpulkan informasi dari informan (wawancara) mengenai sumber bahan alam yang sering digunakan dalam pengobatan berupa: nama daerah, manfaat, bagian yang digunakan, cara pengolahan, cara penggunaan, dan lama penggunaan.

2. Pengumpulan sumber bahan alam

Tanaman yang dikumpulkan dari lokasi penelitian selanjutnya dilakukan determinasi. Tanaman yang disebutkan dalam wawancara tetapi tidak ditemukan di lokasi penelitian, tidak dimasukkan ke dalam data.

3. Analisis sumber bahan alam

Determinasi tanaman dilakukan di Herbarium Biologi, Universitas Padjajaran, Bandung. Selanjutnya pada sampel tanaman dilakukan skrining fitokimia untuk menentukan senyawa metabolit sekunder seperti alkaloid, flavonoid, tanin, saponin, steroid/terpenoid berdasarkan metode skrining fitokimia Harborne (1987) di Laboratorium Penelitian STIKes Harapan Ibu Jambi.

\section{Hasil dan Pembahasan}

Penelitian dilakukan pada SAD di Desa Semambu, Kecamatan Sumay, Kabupaten Tebo, Provinsi Jambi. Jumlah penduduk SAD di Desa Semambu terdiri dari 22 kepala keluarga yang terbagi atas 17 kepala keluarga yang berada di Sungai Ngayur, Desa Semambu dan 5 kepala keluarga yang berada di Sungai Mendelang, Desa Semambu. Masyarakat SAD di Desa Semambu ini masih melakukan tradisi hidup berpindahpindah "Manda". Biasanya jika sedang melakukan manda, mereka hanya bermukim 4-7 hari di suatu tempat lalu berpindah lagi untuk mencari tempat manda yang baru. Hal ini dikarenakan SAD untuk memenuhi kebutuhan hidup 
masih sangat bergantung pada hasil alam. Beberapa masyarakat SAD di Desa Semambu telah memeluk agama Islam meskipun sebagian besar dari mereka masih animisme dan mempertahankan kepercayaan magis leluhur.

Suku Anak Dalam di Desa Semambu selain mengenal pengobatan tradisional, mereka juga telah mengenal pengobatan modern seperti memanfaatkan fasilitas kesehatan seperti Puskesmas. Berdasarkan keterangan dari Tumenggung SAD di Desa Semambu yaitu Tumenggung Bujang Kabut, masyarakat SAD di Semambu sekarang sudah banyak melakukan pengobatan dengan bantuan bidan ataupun tenaga kesehatan Puskesmas untuk menangani penyakit yang serius. Hal ini disebabkan karena sekarang spesies tumbuhan maupun hewan yang digunakan untuk pengobatan yang ada di dalam hutan jumlahnya sudah mulai berkurang dan mengakibatkan mereka sulit untuk mendapatkannya, inilah salah satu alasan mengapa mereka terkadang lebih memilih melakukan pengobatan modern.

Hasil penelitian yang tertera pada Tabel 1. menunjukkan jumlah inventarisasi sumber bahan alam yang terdapat di wilyah SAD di Desa
Semambu, yaitu sebanyak 27 spesies sumber bahan alam yang terdiri dari 22 spesies tumbuhan dan 5 spesies hewan. Jumlah ini lebih sedikit jika dibandingkan dengan penelitian yang dilakukan oleh Indriati (2014) pada SAD di Desa Tabun Kecamatan VII Koto, Kabupaten Tebo, Jambi yang memperoleh 39 spesies. Pengelompokkan tumbuhan maupun hewan dari 27 spesies hasil penelitian ini yaitu diperoleh 22 spesies tumbuhan yang terbagi dalam 15 family dan 5 spesies hewan yang terdiri dari 5 familia (Gambar 1).

SAD di Desa Semambu memanfaatkan tumbuhan maupun hewan untuk pengobatan dari beberapa bagian organ tumbuhan antara lain daun, kulit batang, buah, biji, umbi, akar, getah, dan rimpang. Tidak ada dosis penggunaan yang khusus bagi bahan alam untuk pengobatan SAD di Desa Semambu. Seperti yang disebutkan oleh Jalius (2013) ramuan umumnya memakai ukuran sederhana seperti segenggam, helai, sepucuk, dan ukuran jari. Dapat dilihat bahwa penggunaan organ tanaman yang sering digunakan adalah daun. 
PHARMACY: Jurnal Farmasi Indonesia

p-ISSN 1693-3591

(Pharmaceutical Journal of Indonesia)

Vol.17 No. 01 Juli 2020:172-186

Tabel 1. Sumber bahan alam yang terdapat di Desa Semambu Kecamatan Sumay Kabupaten Tebo Provinsi Jambi

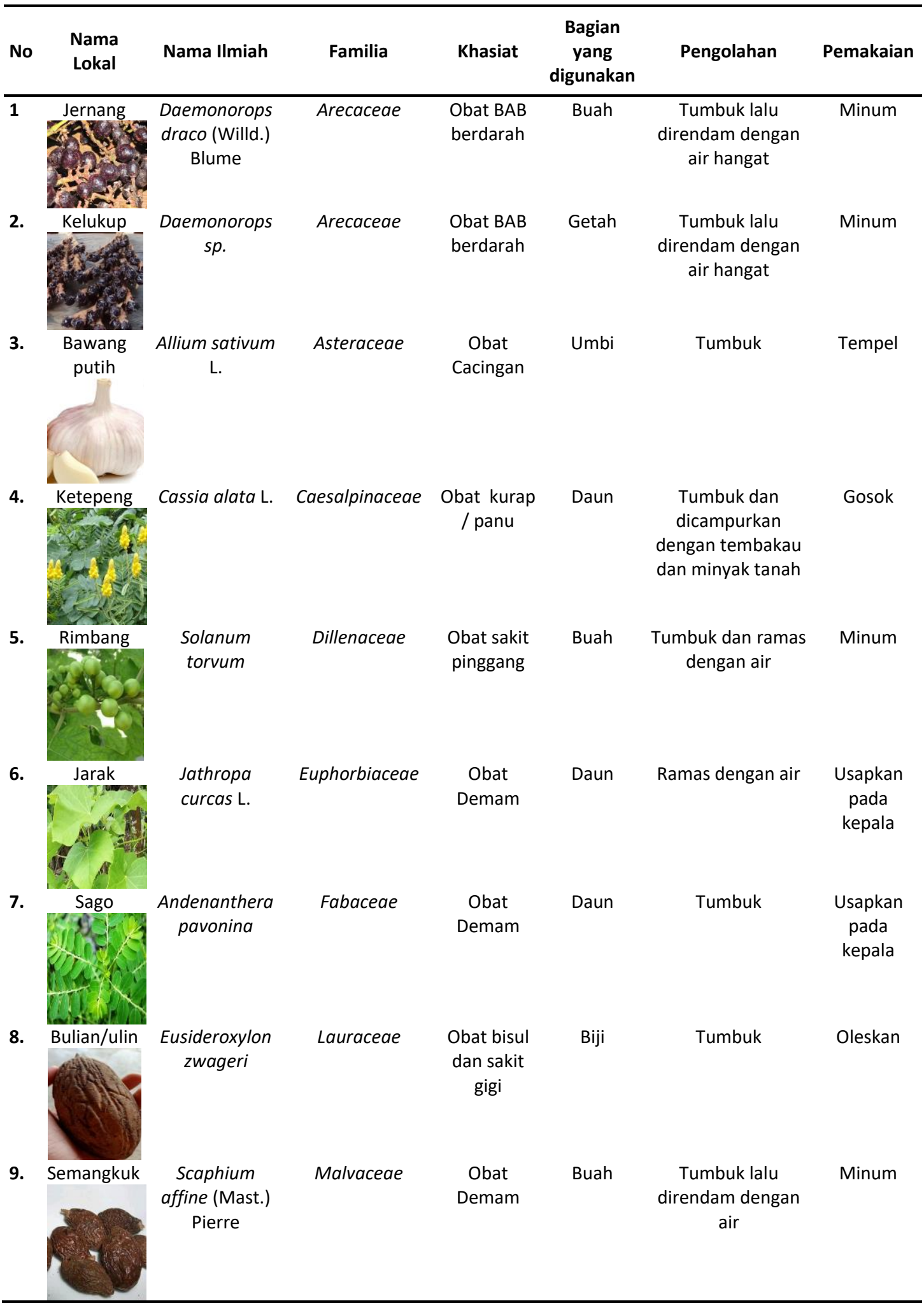


PHARMACY: Jurnal Farmasi Indonesia

p-ISSN 1693-3591

(Pharmaceutical Journal of Indonesia)

Vol.17 No. 01 Juli 2020:172-186

\begin{tabular}{|c|c|c|c|c|c|c|c|}
\hline No & $\begin{array}{l}\text { Nama } \\
\text { Lokal }\end{array}$ & Nama Ilmiah & Familia & Khasiat & $\begin{array}{c}\text { Bagian } \\
\text { yang } \\
\text { digunakan }\end{array}$ & Pengolahan & Pemakaian \\
\hline 10. & Bulc & Clidemia hirta & Melastomaceae & Obat luka & Daun & Tumbuk & Tempel \\
\hline 11. & $\begin{array}{l}\text { Keduduk / } \\
\text { senggani }\end{array}$ & $\begin{array}{l}\text { Melastoma } \\
\text { candidum }\end{array}$ & Melastomaceae & $\begin{array}{c}\text { Obat Sesak } \\
\text { nafas }\end{array}$ & Akar & Rendam & Minum \\
\hline 12. & $\begin{array}{l}\text { Manau } \\
\text { angin }\end{array}$ & $\begin{array}{c}\text { Calamus } \\
\text { manan Miquel. }\end{array}$ & Poaceae & $\begin{array}{c}\text { Obat } \\
\text { Muntaber }\end{array}$ & Buah & Ramas dengan air & Minum \\
\hline 13. & Ilalang & $\begin{array}{l}\text { Imperata } \\
\text { cylindrica }\end{array}$ & Poaceae & $\begin{array}{l}\text { Obat } \\
\text { Demam } \\
\text { disertai } \\
\text { Menggigil }\end{array}$ & $\begin{array}{l}\text { Akar dan } \\
\text { Daun }\end{array}$ & $\begin{array}{c}\text { Tumbuk dan } \\
\text { panaskan diatas api }\end{array}$ & Minum \\
\hline 14. & & $\begin{array}{c}\text { Zingiber } \\
\text { officinale Rosc }\end{array}$ & Rhamnaceae & $\begin{array}{c}\text { Obat } \\
\text { Cacingan } \\
\text { dan Masuk } \\
\text { Angin }\end{array}$ & Umbi & $\begin{array}{l}\text { Tumbuk lalu } \\
\text { diperas }\end{array}$ & Minum \\
\hline 15. & 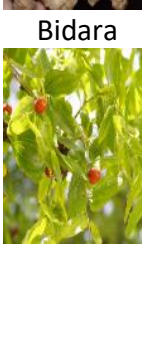 & $\begin{array}{c}\text { Ziziphus jujuba } \\
\text { Mill. }\end{array}$ & Rutaceae & $\begin{array}{l}\text { Obat Sakit } \\
\text { Kepala, } \\
\text { Panas } \\
\text { Dalam dan } \\
\text { Demam }\end{array}$ & $\begin{array}{l}\text { Daun dan } \\
\text { Buah }\end{array}$ & Daun direbus & $\begin{array}{c}\text { Buah } \\
\text { dimakan } \\
\text { langsung } \\
\text { dan } \\
\text { perasan } \\
\text { daun } \\
\text { diusapkan } \\
\text { pada } \\
\text { kepala }\end{array}$ \\
\hline 16. & Jeruk limo & $\begin{array}{l}\text { Citrus } \\
\text { aurantifolia } \\
\text { (Christm.) } \\
\text { Swingle }\end{array}$ & Rutaceae & $\begin{array}{c}\text { Obat } \\
\text { pilek/flu }\end{array}$ & Buah & $\begin{array}{l}\text { Diiris dan diperas } \\
\text { lalu ditambahkan } \\
\text { sedikit garam }\end{array}$ & Minum \\
\hline 17. & Jeruk nipis & $\begin{array}{c}\text { Citrus } \\
\text { aurantifolia }\end{array}$ & Rutaceae & $\begin{array}{c}\text { Obat } \\
\text { demam dan } \\
\text { sakit } \\
\text { tenggorokan }\end{array}$ & Buah & $\begin{array}{c}\text { Buah jeruk diperas } \\
\text { dan dicampurkan } \\
\text { dengan telur ayam } \\
\text { kampung }\end{array}$ & Minum \\
\hline
\end{tabular}


PHARMACY: Jurnal Farmasi Indonesia

p-ISSN 1693-3591

(Pharmaceutical Journal of Indonesia)

Vol.17 No. 01 Juli 2020:172-186

\begin{tabular}{|c|c|c|c|c|c|c|c|}
\hline No & $\begin{array}{l}\text { Nama } \\
\text { Lokal }\end{array}$ & Nama Ilmiah & Familia & Khasiat & $\begin{array}{c}\text { Bagian } \\
\text { yang } \\
\text { digunakan }\end{array}$ & Pengolahan & Pemakaian \\
\hline 18. & Pasak bumi & $\begin{array}{l}\text { Eurycoma } \\
\text { longifolia }\end{array}$ & Simaroubaceae & $\begin{array}{l}\text { Obat Sakit } \\
\text { perut }\end{array}$ & Akar & $\begin{array}{c}\text { Dikikis lalu } \\
\text { dibakar/dipanaskan }\end{array}$ & Tempel \\
\hline 19. & Pecut Kuda & $\begin{array}{l}\text { Stachytarpheta } \\
\text { jamaicensis (L.) } \\
\text { Vahl }\end{array}$ & Verbenaceae & $\begin{array}{c}\text { Obat Panas } \\
\text { dalam dan } \\
\text { batuk }\end{array}$ & Daun & Rebus & Minum \\
\hline 20. & Capo & $\begin{array}{c}\text { Blumea } \\
\text { balsimifera ( L.) }\end{array}$ & Zingiberaceae & Obat Batuk & Daun & Rebus & Minum \\
\hline 21. & & $\begin{array}{l}\text { Curcuma longa } \\
\qquad \mathrm{L} .\end{array}$ & Zingiberaceae & $\begin{array}{c}\text { Obat } \\
\text { wanita } \\
\text { pasca } \\
\text { melahirkan }\end{array}$ & Rimpang & $\begin{array}{l}\text { Tumbuk dan } \\
\text { rendam dengan air } \\
\text { hagat }\end{array}$ & Minum \\
\hline 22. & Sebkal & - & - & $\begin{array}{c}\text { Obat } \\
\text { cacingan }\end{array}$ & $\begin{array}{c}\text { Kulit } \\
\text { batang }\end{array}$ & $\begin{array}{c}\text { Dikikis lalu } \\
\text { dibakar/panaskan } \\
\text { dengan dibungkus } \\
\text { daun }\end{array}$ & $\begin{array}{l}\text { Tempel } \\
\text { diatas } \\
\text { perut }\end{array}$ \\
\hline 23. & Labi-labi & $\begin{array}{l}\text { Dogania } \\
\text { subplana }\end{array}$ & Trionychidae & $\begin{array}{l}\text { Obat gata- } \\
\text { gatal } \\
\text { melepuh } \\
\text { dan kurap }\end{array}$ & Lemak & $\begin{array}{l}\text { Rebus sampai } \\
\text { mengeluarkan } \\
\text { minyak }\end{array}$ & Digosok \\
\hline 24. & Ular Kobra & Naja sputatrix & Elapidae & $\begin{array}{l}\text { Obat BAB } \\
\text { berdarah }\end{array}$ & Empedu & $\begin{array}{c}\text { Rendam dengan air } \\
\text { hangat atau } \\
\text { digoreng }\end{array}$ & $\begin{array}{l}\text { Diminum } \\
\text { dan } \\
\text { dimakan }\end{array}$ \\
\hline 25. & Landak & $\begin{array}{c}\text { Hystrix } \\
\text { javanica }\end{array}$ & Hystricidae & $\begin{array}{l}\text { Obat sakit } \\
\text { gigi }\end{array}$ & $\begin{array}{c}\text { Empedu } \\
\text { dan Taring }\end{array}$ & $\begin{array}{c}\text { Empedu } \\
\text { dipecahkan dan } \\
\text { taring direndam } \\
\text { dengan air hangat }\end{array}$ & $\begin{array}{l}\text { Empedu } \\
\text { dioleskan } \\
\text { dan air } \\
\text { rendaman } \\
\text { taring } \\
\text { dikumur }\end{array}$ \\
\hline 26. & Ular sawo & $\begin{array}{l}\text { Malayophyton } \\
\text { reticulatus } \\
\text { Scheider }\end{array}$ & Pythonidae & $\begin{array}{c}\text { gatal-gatal } \\
\text { dan } \\
\text { melepuh }\end{array}$ & Lemak & $\begin{array}{c}\text { Rebus sampai } \\
\text { mengeluarkan } \\
\text { minyak }\end{array}$ & Digosok \\
\hline
\end{tabular}




\begin{tabular}{|c|c|c|c|c|c|c|c|}
\hline No & $\begin{array}{l}\text { Nama } \\
\text { Lokal }\end{array}$ & Nama Ilmiah & Familia & Khasiat & $\begin{array}{c}\text { Bagian } \\
\text { yang } \\
\text { digunakan }\end{array}$ & Pengolahan & Pemakaian \\
\hline 27. & Biawak & Varanus sp. & Varanidae & $\begin{array}{c}\text { Obat gatal- } \\
\text { gatal }\end{array}$ & Lemak & $\begin{array}{l}\text { Rebus sampai } \\
\text { mengeluarkan } \\
\text { minyak }\end{array}$ & Digosok \\
\hline
\end{tabular}

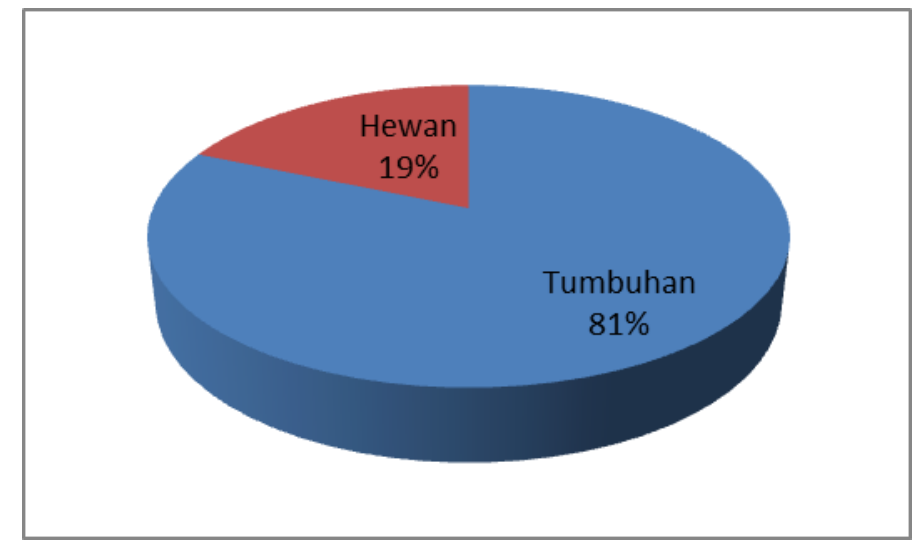

Gambar 1. Sumber bahan alam yang digunakan SAD di Desa Semambu untuk pengobatan.

Indriati (2014) mengatakan bahwa daun merupakan bagian (organ) tumbuhan yang paling banyak digunakan sebagai obat tradisional karena daun umumnya bertekstur lunak karena mempunyai kandungan air yang tinggi (70-80\%). Selain itu, daun merupakan tempat akumulasi fotosintesis yang diduga mengandung unsur-unsur (zat organik) yang berkhasiat menyembuhkan penyakit. Selain dari segi khasiat, faktor lain yang ikut mempengaruhi penggunaan daun sebagai obat meliputi kemudahan dalam pengumpulannya, penyimpanan yang dapat bertahan lama apabila dikeringkan, dan mudahnya ekstraksi senyawa di dalamnya (Affandi et al., 2004).

Pada umumnya masyarakat SAD di Desa Semambu dalam memanfaatkan sumber bahan alam untuk pengobatan ataupun untuk kebutuhan lainnya masih sangat sederhana dan tradisional berdasarkan pengetahuan secara turun temurun dari leluhurnya. Adapun cara pengolahan yang sering dilakukan yakni ditumbuk, direbus, direndam, dipanaskan (dibakar), dan diperas. Metode pengolahan obat yang paling sering digunakan adalah dengan cara ditumbuk, hal ini dianggap lebih sederhana, lebih mudah dilakukan, dan tidak memerlukan waktu lama serta alat yang khusus untuk mengolahnya. Cara 
penggunaan obat pada masyarakat $S A D$ antara lain diminum, ditempelkan, diusapkan, dikumur, dikunyah, dimakan, dioles, dan digosok di tempat yang terasa sakit.

Pengobatan tradisional dengan menggunakan hewan, organ yang digunakan seperti empedu, taring (gigi/saing), dan lemak/minyak yang dihasilkan dari rebusan/dengan cara membakar hewan yang akan dijadikan obat sampai diperoleh minyaknya, kemudian minyak tersebut dioleskan pada bagian yang membutuhkan. Cara penggunaannya yang paling sering digunakan untuk ramuan tumbuhan yaitu dengan cara diminum sebanyak 2 kali sehari pada pagi dan sore. Pengobatan tidak menggunakan takaran/dosis yang khusus, untuk anakanak dapat digunakan secukupnya dan untuk orang dewasa dapat mengkonsumsi setengah gelas ramuan. Apabila penyakit sudah dirasa membaik, maka pengobatan dapat dihentikan. Jika tidak terdapat perubahan, maka masyarakat SAD menganggap obat yang digunakan tidak cocok dan menggantinya dengan pengobatan lain.

Berdasarkan hasil wawancara yang telah dilakukan terhadap informan, diketahui beberapa jenis penyakit yang sering diobati menggunakan sumber bahan alam baik tumbuhan maupun hewan oleh masyarakat SAD di Desa Semambu. Berikut beberapa contoh cara pengolahan sumber bahan alam untuk pengobatan yang sering digunakan $S A D$ di Desa Semambu, Kecamatan Sumay, Kabupaten Tebo, Provinsi Jambi.
Tanaman ketepeng (Cassia alata L.) digunakan SAD di Desa Semambu sebagai obat untuk mengatasi penyakit kulit seperti gatal-gatal, kurap, panu, dan kudis. Cara pengolahannya yaitu dengan cara beberapa lembar daun ketepeng dibersihkan lalu ditumbuk dengan ditambahkan tembakau cap ayam sampai halus, lalu ditambahkan sedikit minyak makan dan digosokkan pada tempat yang gatal. Pengobatan dan pengolahan daun ketepeng oleh SAD di Desa Semambu ini juga sama dengan cara pengobatan oleh SAD di Desa Muara Kilis, Kecamatan Tengah Ilir, Kabupaten Tebo, Provinsi Jambi, dan Suku Batin di Kecamatan Tabir, Kabupaten Merangin, Provinsi Jambi yang juga memanfaatkan daun ketepeng sebagai obat gatal, panu, kurap, dan kudis dengan cara dioleskan (Jalius, 2013). Daun ketepeng juga digunakan sebagai antiparasit, eksim, malaria, sembelit, radang pada kulit, sifilis, herpes, influenza, dan bronkitis (Perawati et al., 2019). Daun ketepeng mengandung flavonoid, alkaloid, antrakuinon, saponin, dan tanin (Octarya \& Saputra, 2015). Hasil skrining fitokimia serbuk simplisia daun ketepeng menunjukkan bahwa serbuk daun ketepeng mengandung flavonoid, tanin, dan saponin.

Tanaman pasak bumi (Eurycoma longifolia) digunakan SAD di Desa Semambu sebagai obat untuk mengatasi sakit perut terutama pada anak-anak. Bagian yang digunakan dari tanaman ini adalah bagian akar. Cara pengolahannya yaitu dengan cara mengikis akar 
tanaman pasak bumi yang sudah dibersihkan lalu dibungkus dengan dedaunan kemudian diletakkan di atas api. Kemudian diletakkan di atas bagian perut anak yang terasa sakit. Sementara itu, pada etnis Batak, pasak bumi dimanfaatkan sebagai obat sakit perut, demam, malaria, dan penambah stamina (Silalahi \& Nisyawati, 2015). Berdasarkan penelitian tersebut, akar dan daun pasak bumi mengandung kuasinoid yang memiliki rasa pahit yang diyakini berkhasiat sebagai obat demam, sedangkan tumbuhan yang sangat pahit diyakini untuk pengobatan malaria. Daun pasak bumi mengandung terpenoid, flavonoid, alkaloid, fenolik, dan saponin sedangkan bagian akar mengandung terpenoid, alkaloid, dan fenolik (Zulfahmi, 2018). Hasil skrining fitokimia serbuk daun pasak bumi mengandung alkaloid, falvonoid, tanin, dan steroid sedangkan bagian akar mengandung senyawa alkaloid.

Tanaman capo (sembung/ Blumea balsimifera L.) digunakan SAD di Desa Semambu sebagai obat untuk mengatasi gatal pada kerongkongan dan batuk. Bagian yang digunakan adalah daunnya dengan cara dibersihkan lalu direbus dengan air secukupnya kemudian air saringan diminum. Metode pengobatan ini sama dengan metode pengobatan yang dilakukan oleh masyarakat SAD di Desa Muara Kilis, Kecamatan Tengah Ilir, Kabupaten Tebo Provinsi Jambi, sedangkan masyarakat di Muara Bengkahulu, Kabupaten Bengkulu, menggunakan daun capo sebagai obat demam dengan cara daun capo diperas dan diambil airnya kemudian dikompreskan pada bagian kepala (Perawati et al., 2019). Daun capo mengandung kamper, borneol, glikosida, minyak essensial, tanin, saponin, resin, dan xanthocylyn. Berdasarkan hasil skrining fitokimia serbuk daun capo yang dikenal dengan daun sembung mengandung flavonoid dan tanin.

Di Desa Semambu, buah jernang (Daemorops druco Wild. Blume) dimanfaatkan SAD sebagai obat BAB berdarah dengan cara buah jernang dihancurkan kemudian direndam dengan air panas secukupnya lalu disaring dan air hasil saringan diminum. Adapun saat mengalami gangguan kesehatan seperti ini tidak dianjurkan untuk mengkonsumsi makanan yang pedas. Sementara itu, SAD di Desa Muara Kilis, Kecamatan Tengah Ilir, Kabupaten Tebo, Provinsi Jambi, buah jernang juga dapat digunakan untuk pengobatan sakit perut batuk darah, disentri, dan setelah melahirkan dengan cara buah jernang dihancurkan kemudian dicampurkan dengan kunyit dan segelas air lalu disaring dan diminum. Masyarakat SAD Bukit Dua Belas, Kabupaten Sarolangun, Jambi menggunakan getah dari jernang sebagai obat sakit kepala, luka, demam, dan diare (Andika et al., 2015). Komponen utama yang terkandung dalam jernang yaitu ester, resin, flavonoid, asam benzoylacetic, tanin, saponin, steroid/terpenoid (Perawati et al., 2019). Berdasarkan skirining fitokimia jernang mengandung alkaloid, flavonoid, saponin, dan terpenoid. 
Masyarakat SAD di Desa Semambu menggunakan lemak/minyak dari labi-labi (Dogania subplana) sebagai obat gatal-gatal, melepuh, kurap, panu, dan kudis. Cara memperoleh lemak/minyak dari hewan ini, daging labi-labi direbus dengan air ataupun dibakar sampai mengeluarkan minyak, kemudian minyak ini digosokkan pada bagian tubuh yang terasa gatal. Selain itu, labi-labi juga digunakan oleh SAD di Desa Muara Kilis dan dapat digunakan sebagai obat untuk sesak napas dengan cara dagingnya digoreng dan dimakan (Perawati et al., 2019). Sedangkan pada masyarakat Dayak Belangin di Desa Mu'un, Kecamatan Ngabang, Kabupaten Landak memanfaatkan labi-labi sebagai obat asma dan malaria dengan cara empedu dapat dimakan secara langsung dan dagingnya digoreng dan dimakan (Heningsih et al., 2018). Masyarakat di Sumatera Barat juga menggunakan semua bagian tubuh labi-labi kecuali organ dalam untuk mencegah ejakulasi dini dan mencegah penyakit kelamin (Hamdani et al., 2013).

Masyarakat SAD di Desa Semambu menggunakan lemak/minyak dari biawak (Varanus sp.) sebagai obat gatal-gatal. Untuk memperoleh lemak/minyak dari hewan ini daging biawak direbus dengan air ataupun dibakar sampai mengeluarkan minyak kemudian minyak ini digosokkan pada bagian tubuh yang terasa gatal. Daerah DKI Jakarta juga menggunakan biawak yang sudah diolah menjadi bentuk kapsul untuk pengobatan gatal-gatal pada tubuh, eksim, koreng, panu, kadas, dan kurap dengan cara diminum atau dimakan (Arisnagara, 2009), sedangkan masyarakat di Desa Mu'un, Kecamatan Ngabang, Kabupaten Landak juga memanfaatkan biawak sebagai obat asma, flu, dan penawar bagi gigitan hewan berbisa dengan cara pengalahan yakni empedu biawak dikeringkan dan direbus kemudian dapat diminum ataupun dioles (Heningsih et al., 2018).

Masyarakat SAD di Desa
Semambu memanfaatkan landak (Hystrix javanica) dalam pengobatan sebagai obat sakit gigi. Cara pengolahannya yaitu dengan menggunakan bagian empedu dan taring pada hewan landak. Bagian empedu landak dapat dioleskan langsung pada bagian yang terasa sakit dan taring landak dapat dikikis dan dibersihkan lalu direndam dengan air panas secukupnya kemudian dikumurkumur selama kurang lebih $1 / 2$ menit dan airnya dibuang. Pemanfaatan landak dalam pengobatan juga dilakukan oleh masyarakat di Desa Mu'un, Kecamatan Ngabang, Kabupaten Landak, salah satunya menggunakan usus landak untuk mengobati malaria dan tipes dengan cara digoreng kemudian dimakan (Heningsih et al., 2018). Sedangkan pada masyarakat Suku Dayak Sebaruk di Desa Setunggul, Kecamatan Silat Hilir, Kabupaten Kapuas Hulu, duri dan geliga pada landak dimanfaatkan sebagai obat sakit kuning, liver, penawar racun, dan sakit pinggang dengan cara geliga dikeringkan dan diseduh dengan menggunakan air hangat dan airnya diminum, untuk durinya ujung duri landak dibakar lalu dioleskan (Krisyanto et al., 2019). 
SAD di Desa Semambu juga menggunakan hewan untuk pengobatan seperti ular kobra (Naja sputatrix) yang digunakan sebagai obat saat BAB berdarah. Bagian yang digunakan dalam pengobatan ini yaitu empedu ular yang diolah dengan cara ditambahkan air hangat dan diminum. Empedu ini dapat pula dimakan secara langsung. Sedangkan SAD yang berada di Muara Kilis, Kecamatan Tengah Ilir, Kabupaten Tebo, Provinsi Jambi juga menggunakan ular kobra sebagai pengobatan luar yang digunakan untuk penyakit panu, kudis, dan kurap dengan cara menerapkan darah ular ke bagian tubuh yang terasa gatal. Hasil penelitian Kartikasari (2008) juga diketahui bahwa orang-orang di Daerah Jawa Tengah juga memanfaatkan ular kobra sebagai obat kanker, liver, stroke, penyakit kulit (gatal, eksim, alergi) sakit pada pernapasan, tekanan darah rendah, dan meningkatkan stamina. Di daerah Bogor, Jawa Barat ular kobra selain dimanfaatkan sebagai obat penyakit kulit, juga dimanfaatkan untuk mencegah mata cepat lelah, menetralkan racun di dalam tubuh, meningkatkan stamina dan gairah seksual (Situngkir, 2009).

Keberadaan sumber bahan alam yang digunakan oleh SAD di Desa Semambu jika dibandingkan dengan hasil penelitian yang dilakukan oleh Affandi et al. (2004) di Pasir Mayang Jambi terdapat 57 koleksi maka sumber bahan alam yang ada di wilayah SAD di Desa Semambu yaitu 47,4\%. Bila dibandingkan dengan tumbuhan obat yang ditemukan di Indonesia saat ini dengan hasil koleksi lebih kurang 20.000 jenis tumbuhan obat menurut Indriati (2014), maka tumbuhan obat yang digunakan oleh SAD di Desa Semambu hanya $0,14 \%$.

\section{Simpulan}

Sumber bahan alam yang diperoleh dari Desa Semambu, Kecamatan Sumay, Kabupaten Tebo, Provinsi Jambi untuk pengobatan sebanyak 27 spesies yang terdiri dari 22 spesies tumbuhan dan 5 spesies hewan. Penyakit yang paling sering diobati dengan bahan alam yaitu penyakit kulit seperti gatal-gatal. Bagian tanaman yang paling banyak digunakan adalah daun dan cara pengolahan yang paling sering dilakukan yaitu dengan cara ditumbuk dan direbus.

\section{Daftar Pustaka}

Affandi, H., Nuryadin, A., Prayogo, S. 2004. Medicinal herbs of Pasir Mayang, Jambi: ethnopharmacy and toxicity screening. Jurnal Biotropia, 22:40-58.

Andika, Rana, R., Hariyadi, B., Saudagar, F. 2015. Etnobotani penghasil getah oleh Suku Anak Dalam di Taman Nasional Bukit Duabelas Kabupaten Sarolangun, Jambi. Jurnal IImu Pertanian Indonesia, 20:33-38.

Arisnagara, F. 2009. Pemanfaatan reptil sebagai obat dan makanan di Daerah Khusus Ibu Kota (DKI) Jakarta. Skripsi. Institut Pertanian Bogor.

Hamdani, R., Tjong, D.H., Herwina, H. 
2013. Potensi herpetofauna dalam pengobatan tradisional di Sumatera Barat. Jurnal Biologi Universitas Andalas, 2(2):110117.

Harborne, J.B. 1987. Metode Fitokimia: Penuntun Cara Modern Menganalisis Tumbuhan. Bandung: Institut Teknologi Bandung.

Heningsih, M., Anwari, Sofwan, M., Yani, A. 2018. Kajian etnozoologi untuk obat-obatan masyarakat Dayak Belangin di Desa Mu'un Kecamatan Ngabang Kabupaten Landak. Jurnal Hutan Lestari, 6: 647-653.

Indriati, G. 2014. Etnobotani tumbuhan obat yang digunakan suku anak dalam di Desa Tabun Kecamatan VII Koto Kabupaten Tebo Jambi. Jurnal Sainstek, VI(1):52-56.

Jalius, M. 2013. Eksplorasi pengetahuan lokal tentang tumbuhan obat di Suku Batin, Jambi. Jurnal Biospecies, 6:28-36.

Kartikasari, D. 2008. Keanekaragaman jenis dan nilai ekonomi satwa liar yang digunakan sebagai obat di Jawa Tengah. Tesis. Sekolah Pascasarjana, Institut Pertanian Bogor.

Krisyanto, Ruly, D., Ardian, H., Anwari, Sofwan, M. 2019. Kajian etnozoologi untuk pengobatan Suku Dayak Sebaruk di Desa Setunggul Kecamatan Silat Hilir Kabupaten Kapuas Hulu. Jurnal Hutan Lestari, 7:1282-1289.

Octarya, Z., Saputra, R. 2015. Pengaruh jenis pelarut terhadap jumlah ekstrak dan daya antifungi daun ketepeng cina (Cassia alata L.) terhadap jamur Trychophyton Sp. Jurnal Photon, 5(2):15-21.

Perawati, S., Andriani, L., Anggresani, L., Ardila, E. 2019. Ethnopharmacy studi Suku Anak Dalam (SAD) di Muara Kilis Village, Tengah Ilir, Kabupaten Tebo, Provinsi Jambi. Jurnal Biospecies, 12(2):35-41.

Saleh, S. 2014. Agama, kepercayaan dan kelestarian lingkungan studi terhadap gaya hidup orang rimba menjaga lingkungan di Taman Nasional Bukit Dua Belas (TNBD)-Jambi. Kawistara: Jurnal Ilmiah Sosial dan Humaniora, 4(3):225-330.

Silalahi, M., Nisyawati. 2015. Etnobotani pasak bumi (Eurycoma longifolia) pada etnis Batak, Sumatera Utara. Prosiding Seminar Nasional Masyarakat Biodiversitas Indonesia, 1(4):743-746. 21 Maret, Yogyakarta.

Situngkir, S.V.R. 2009. Perdagangan dan pemanfaatan ular secara tradisional di Wilayah Bogor. Skripsi. Departemen Konservasi Sumberdaya Hutan dan Ekowisata, Fakultas Kehutanan, Institut Pertanian Bogor.

Willy, Erizal, Musri, N. 2019. Laporan Assesment Marga/Batin dan Orang Rimba Bukit Duabelas. Jambi: Kelompok Kerja Sosial Regional Jambi.

Zulfahmi. 2018. Perbandingan kandungan dan konsentrasi 
PHARMACY: Jurnal Farmasi Indonesia

p-ISSN 1693-3591

(Pharmaceutical Journal of Indonesia)

e-ISSN 2579-910X

Vol.17 No. 01 Juli 2020:172-186

bahan aktif akar dan daun pasak

Universitas Islam Negeri Sultan

bumi. Laporan Penelitian.

Syarif Kasim Riau. 